DOUTRINA

\title{
ATO ADMINISTRATIVO: CONCEITO E ELEMENTOS
}

Clenir de Assis Lopes

\section{INTRODUC̣ĀO}

O tema, Ato Administrativo, conceito e elementos, impõe a formulação de algumas considerações iniciais necessárias à compreensão genérica do assunto. Destaca-se em primeiro plano a noção de Administração Pública, fundada nos critérios subjetivo ou orgânico, objetivo ou material e critério formal.

Quanto ao Ato Administrativo será abordado segundo suas características, em confronto com o ato jurídico e outros atos da Administração e sua conceituação.

Nossa proposta de sistematização do tema será apresentada após o exame do problema da estrutura do Ato Administrativo e dos elementos que o compõem.

\author{
SUMĀRIO \\ CAPITULO I
}

\section{ADMINISTRAC̣ĀO PÜBLICA}

1. Noção de Administração Pública

2. Critérios adotados para conceituar Administração Pública
A) Critério subjetivo ou orgânico
B) Critério objetivo ou material
C) Critério formal 


\section{CAPITULO II}

\section{ATO ADMINISTRATIVO}

1. Noção de ato administrativo . . . . . . . . . . . . . . . . .

A) Ato administrativo e ato de administração

B) Características do ato administrativo

a) Ato jurídica e ato administrativo ...............

b) Ato administrativo e os outros atos estatais

2. Conceito de ato administrativo

\section{CAPITULO III \\ ESTRUTURA DO ATO ADMINISTRATIVO}

1. Anatomia do ato administrativo ................

A) Elementos do ato administrativo

2. Conclusão

A) Requisitos do ato administrativo

B) O papel da vontade no ato administrativo

C) Elemento do ato administrativo

BIBLIOGRAFIA

\section{CAPITULO I \\ ADMINISTRAC̣ĀO PÚBLICA}

\section{NOC̣ĀO DE ADMINISTRAC̣ĀO PÜBLICA.}

A sociedade política, uma vez organizada pela Constituição, se condiciona a atuar conforme os poderes negativos e positivos descritos e definidos pelo Direito Constitucional.

$\mathrm{Na}$ escala de valores da ordem social, a utilidade pública se constitui no objetivo primeiro da atividade propriamente pol ítica da sociedade, tanto no que tange às relações de direito privado (entre os particulares) como no que se refere às relações de direito público (as que se estabelecem entre particulares e a própria sociedade, através da instituição governamental).

O cumprimento deste objetivo configura uma atividade de caráter político do Estado - a função administrativa - e se traduz na criação de utilidade pública. 
A esta função administrativa corresponde um ramo jurídico, perfeitamente caracterizado: o Direito Administrativo.

Pode-se dizer que a atividade administrativa, sob o ponto de vista estritamente material, existe desde que o homem vive em sociedade organizada. O nascimento, contudo, de um conjunto relativamente sistematizado de normas - o Direito Administrativo - coincide com o surgimento do Estado de Direito. ${ }^{1}$

É fácil compreender porque assim ocorreu. Basta relembrarmos que enquanto perdurou o absolutismo, todos os poderes pertenciam integralmente ao soberano. Com a queda desse regime puderam ser aplicadas as teorias que preconizavam a separação dos poderes em: Poder Legislativo, Poder Executivo e Poder Judiciário. Esta divisão tornou-se realidade nas Constituições elaboradas e decorrentes do advento do Constitucionalismo. Nesse exato momento estruturou-se igualmente a Administração Pública. As instituições administrativas e os preceitos relativos à Administração até então existentes, - existência porém negada pelo Estado absoluto - agora tomavam corpo, revestindo-se de caráter cient ífico e recebendo sistematização.

Devidamente estruturada a Administração Pública e distinta das demais funções do Estado, abriu-se oportunidade para o surgimento do Direito Administrativo.

Pelo que se pode depreender da doutrina, não existe controvérsia quanto ao reconhecimento de ser a Administração Pública o objeto do Direito Administrativo. Mas se até este ponto não há divergências, estas começam a surgir no momento de se definir o que seja Administração Pública. Vale ressaltar, contudo, que tais discrepâncias não exercem qualquer influência no conteúdo do Direito Administrativo $^{2}$ e que, na verdade, decorrem mais de desacordos semânticos, ou como acentua Fernando Andrade de Oliveira, "a variedade dos critérios adotados traduz, portanto, mais uma diversidade de forma que de fundo". ${ }^{3}$

Dependendo, pois, do critério adotado decorrem esta ou aquela definição de Administração Pública.

\section{CRITÉRIOS ADOTADOS PARA CONCEITUAR ADMINISTRA- ÇĀO PÜBLICA.}

Sem pretensão de esgotarmos aqui o assunto e atendendo tão somente à necessidade de uma sistematização, mencionaremos, de forma abreviada, os critérios predominantemente utilizados na conceituação da Administração Pública e que se referem aos aspectos subjetivo ou orgânico, objetivo ou material e formal.

\footnotetext{
${ }^{1}$ CASSAGNE, Juan Carlos. El Ato Administrativo, 2a ${ }^{\mathrm{a}}$. ed., Abeledo-Perrot, Buenos Aires. p. 55 .

${ }^{2}$ CASSAGNE, Juan Carlos. Op. cit. p. 58.

${ }^{3}$ OLIVEIRA, Fernando Andrade de. Conceituação do Direito Administrativo. Anais do I Congresso Brasileiro de Direito Administrativo, Curitiba, 1975. p. 100.
} 
A) Critério subjetivo ou orgânico.

A atividade do Estado é exercida por certos e determinados órgãos estatais ou de outras entidades. Sob este aspecto é que se observa a Administração Pública, ou seja, ela é definida pela fonte de produção de onde emana, seja de órgãos, seja de sujeitos.

Neste sentido a Administração Pública nos é revelada como um todo orgânico do qual participam autoridades, funcionários, agentes públicos, etc., dispostos hierarquicamente em distintos planos e devidamente coordenados.

Em outros termos, define-se a Administração Pública, sob o ponto de vista subjetivo, como o conjunto de órgãos que formam e dinamizam o aparelho administrativo do Estado, tendo como competência característica a função administrativa.

B) Critério objetivo ou material.

O critério objetivo prende-se à atividade prática da Administração Pública, a qual compreende a satisfação concreta e imediata das necessidades coletivas. Através deste prisma a Administração Pública já não é encarada sob seu aspecto estrutural, vale dizer, já não é focalizada como um conjunto de órgãos. A Administração Pública exerce suas atividades para satisfazer interesses públicos e é pelo desempenho de tais atividades que ela é definida objetivamente. Daí podermos dizer que ela correponde à atividade prática desenvolvida pelo Estado no exercício de sua competência e para cumprimento de sua finalidade, isto é, para a satisfação concreta e imediata das necessidades coletivas.

\section{C) Critério formal}

Como bem nos esclarece o Professor Fernando Andrade de Olivei$\mathrm{ra}^{4}$, o critério formal não se confunde com o subjetivo ou orgânico, não obstante o fato de alguns autores se referirem à concepção orgânica ou formal, ao identificarem a Administração Pública pela origem. Considera mais acertado, o referido autor, reservar o critério formal para definir a Administração Pública sob outras características, distintas estas da origem (caráter subjetivo) e do conteúdo (caráter material).

A definição de Administração Pública sob o aspecto formal compreende a eficácia jurídica de seus atos. Assim, ela é identificada como a atividade do Estado exercida sob a Constituição e sob a lei formal, ou seja, sob o mandamento jurídico.

Ressalte-se que a eficácia dos atos administrativos se reveste de caráter provisório, posto que são passíveis de anulação pelos órgãos

${ }^{4}$ Op. cit., p. 142. 
jurisdicionais, uma vez que sejam reconhecidos como lesivos a interesses públicos ou privados, juridicamente protegidos.

Sob o aspecto formal tem-se, então, que a Administração Pública "é o conjunto das atividades do Estado que, na execução e aplicação da lei formal e no exercício do poder público, são realizadas mediante procedimentos próprios, decompondo-se em atos administrativos, tipificados pela auto-executoriedade, mas de caráter provisório, posto que estão sujeitos à anulação, também por via jurisdicional, desde que ilegais e lesivos a interesses juridicamente protegidos" ${ }^{\prime \prime}{ }^{5}$

Dissemos, de início, que as discordâncias no momento de definir a Administração Pública são mais de forma que de fundo. De fato, verificamos que os três critérios abordados prendem-se, cada um deles, a um determinado aspecto da Administração Pública e quando esta é assim definida adquire a conceituação que se refere a cada critério em particular. Uma definição que ao memo tempo englobe esses três critérios permitirá uma visão global da Administração, em todos os seus aspectos: o da estrutura (aspecto subjetivo), o da atividade prática direta e imediata (aspecto objetivo) e o da eficácia jurídica ou legalidadeı (aspecto formal).

A Administração Pública pode ser assim entendida como a realização de atividades que visam um determinado fim (fim público), desenvolvidas de forma concreta e imediata e exercidas por estrutura orgânica, sob o ordenamento jurídico.

${ }^{5}$ Cf., lição de Fernando Andrade de Oliveira, Op. cit. 152. 


\section{CAPITULO II}

\section{ATO ADMINISTRATIVO}

\section{NOÇĀO DE ATO ADMINISTRATIVO.}

A Administração Pública, no desempenho de suas atividades, vale-se de procedimentos próprios identificados como atos administrativos.

Uma vez mais estamos diante de matéria extremamente controversa face à inexistência de uma definição legal de ato administrativo.

De modo geral as discordâncias prendem-se à composição do ato administrativo. Melhor dizendo, não são concordes os autores quanto à enumeração e identificação dos elementos necessários à formação do ato para que adquira caráter de ato administrativo. Não obstante discordâncias conceituais, os tratadistas convergem para um ponto de apoio comum e "se pacificam em reservar esta expressão a atos correspondentes ao exercício de funções típicas do Executivo, a dizer, expressivas das manifestações estatais que, normalmente, são peculiares a este conjunto orgânico (“PODER")". 6

Reveste-se de importância a exata determinação da noção de ato administrativo pela necessidade de distinguí-lo dos demais atos do poder estatal, aqueles emanados do Legislativo e do Judiciário, bem como dos atos de direito privado.

Partindo do levantamento de tais distinções e aduzindo, em seguida, características que possam ser atribuídas como peculiares ao ato administrativo, nos aproximaremos da correta noção desta espécie.

Este é o método básico proposto por Celso Antônio Bandeira de Mello $^{7}$, no qual nos apoiaremos não só porque consideramos um bom critério para o fim a que se propõe como também para o estabelecimento de um ponto de partida que nos forneça subsídios suficientes para nos encaminhar à formulação de conclusões pessoais sobre o tema.

O que se observa é que os administrativistas via de regra se valem deste critério restritivo na busca do estabelecimento de uma no-

\footnotetext{
${ }^{6}$ MELLO, Celso Antônio Bandeira de. Ato Administrativo e Direitos dos Administrados, Ed. Revista dos Tribunais, São Paulo, 1981. p. 8.

${ }^{7}$ Op. cit., p. 11.
} 
ção de ato administrativo, isolando, assim, um grupo particular de atos de outros dois grupos - dos legislativos e dos jurisdicionais.

A) Ato administrativo e ato de administração.

Ao falar-se de Administração, a referência se infere não apenas aos seus órgãos centrais mas também às entidades autárquicas e, ainda, em certos casos, a pessoas privadas que pratiquem funções públicas por delegação do Poder Público. Tanto aqueles (os órgãos centrais) como estes (entidades autárquicas e pessoas privadas) praticam atos administrativos, que são assim considerados porque produzem efeito jurídico, isto é, de sua prática decorrem modificações jurídicas.

Outros atos há que, embora emanados da Administração, não visam qualquer alteração no mundo jurídico e não possuem, por esta razão, as características do primeiro, como por exempio, de criar, alterar ou extinguir direitos. Estes pertencem à categoria dos atos de administração.

Tem-se, assim, que será um erro considerar tais atos como sinônimos, muito embora nem todos os administrativistas considerem as distinções apontadas e sejam da opinião de que todos os atos praticados pela Administração podem ser incluídos na categoria de atos administrativos.

B) Características do ato administrativo.

a) Ato jurídico e ato administrativo

$\mathrm{O}$ ato jurídico recebe da legislação uma definição, tal como nosso Código Civil estabelece no art. 81: "todo o ato lícito que tenha por fim imediato adquirir, resguardar, transferir, modificar ou extinguir direitos"'.

Uma vez que se considere o ato jurídico como o gênero ao qual pertence $o$ ato administrativo como espécie, tem-se que este deve conter as caracter ísticas daquele. Reproduzindo as características genéricas do ato jurídico, tendo por fim o interesse coletivo, que é a finalidade da Administração Pública, o ato toma feição própria, caracter ísticas próprias, que o colocam em uma categoria também própria de atos, no

\footnotetext{
${ }^{8}$ Oswaldo Aranha Bandeira de Mello nos ensina que não se confundem o ato administrativo e o ato de administração. Este é qualquer ato da Administração Pública (de atividade material, de execução de obra ou de prestação de serviço); ou então o jurídico, praticado "enquanto poder público, ou nas condições de um particular". Pertencem à categoria de ato administrativo somente os atos jurídicos dos órgãos administrativos, enquanto poder público, ou seja, aqueles que representam a manifestação da vontade do Poder Público. (Princípios Gerais de Direito Administrativo, v. 1, $2^{\mathrm{a}}$ ed., Forense, Rio de Janeiro, 1979. p. 461).

No mesmo sentido, Fortshoff lembra que sendo o ato administrativo um conceito jur ídico que tem portanto, um papel a cumprir no Direito, só se pode incluir nesta categoria aqueles atos dos quais somente emane diretamente um efeito jurídico. (Tratado de Derecho Administrativo, Instituto de Estudios Políticos, Madrid, 1958. p. 282).
} 
conjunto dos demais atos estatais ou de direito privado que defluem do ato jurídico como gênero. Daí podermos acompanhar o mestre Hely Lopes Meirelles ${ }^{9}$ quando assevera que "A Administração Pública realiza sua função executiva por meio de atos jurídicos que recebem a denominação especial de atos administrativos".

Ao afirmar-se que o ato administrativo deve atender a um fim predeterminado - o interesse comum, que é o fim que a Administração Pública busca atingir - já se estabelece a esta espécie uma condição especial que a distingue do ato de direito privado e que é concernente à autonomia da vontade. Vale dizer, estando previamente determinado o fim da Administração, ao sujeito não é facultada a liberdade de querer de forma contrária ao que está estabelecido. A ele só é atribuído o dever de querer atingir o fim legalmente estabelecido.

Difere largamente o ato administrativo, neste ponto, do ato de direito privado cuja essência se traduz pela autonomia de vontade. Difere, de igual modo, quanto ao interesse visado: enquanto o ato de direito privado tem por fim a satisfação de interesses individuais ou particulares, o ato administrativo deve ser dirigido à satisfação de interesses coletivos.

Mas não basta que se atenha simplesmente ao interesse público, pois ele deve ser específico, determinado, aquele que provocou a previsão do ato. $\mathrm{O}$ ato jurídico de direito privado permite a utilização de vias distintas, desde que lícitas, para alcançar um fim também lícito. Por seu turno, o ato administrativo está vinculado à finalidade pela tipicidade, ou seja, o ato é previsto para um fim identificado como típico dele.

Outro princípio que se impõe ao ato administrativo é o do formalismo. Se no direito privado o que norteia o ato é o princípio do informalismo, isto é, da liberdade de forma exceto quando haja determinação em contrário, o ato administrativo está sujeito a determinados requisitos formalísticos.

Como bem ensina o Professor Celso Antônio ${ }^{10}$, estas características até aqui mencionadas, quais sejam, função, interesse, tipicidade e formalismo, se traduzem em garantias individuais.

A função administrativa, como já ficou assente, volta-se aos interesses coletivos. Assim, impõem-se determinados requisitos à atuação da Administração a fim de que seus atos sejam compatíveis com seus fins e para que aos administrados sejam dadas garantias de que os atos administrativos são compatíveis com aqueles interesses e, portanto, conformes com a lei. Mantida tal compatibilidade têm os administrados assegurada a garantia de uma Administração Pública pautada no

\footnotetext{
${ }^{9}$ MEIRELlES, Hely Lopes. Direito Administrativo Brasileiro, $2^{\mathrm{a}}$ ed., Ed. Revista dos Tribunais, São Paulo, 1982. p. 149.

${ }^{10}$ Op. cit., p. 20.
} 
princípio da legalidade ${ }^{11}$ e a Administração, por sua vez, tem assegurados o exercício de suas prerrogativas e o desempenho pleno de suas atribuições. Ressalte-se que nessa relação que se estabelece entre a Administração e a lei não basta só a compatibilidade. Esta pressupõe conformidade e submissão.

Soma-se ao princípio da legalidade o da presunção de legitimidade. Justamente porque o ato administrativo deve ocupar-se da aplicação da lei, existe a presunção de que seja sempre expedido em conformidade com a norma jurídica. Acrescente-se, ainda, que sendo seu objetivo a satisfação de interesses públicos, acima dos individuais portanto, pressupõe-se que esteja imune ao risco de ter seu fim desvirtuado, por abuso de poder e para satisfação de interesses pessoais. No ato jurídico de direito privado, inversamente, não se verifica essa presunção de legitimidade exatamente porque ele tem por fim a realização de interesses do agente.

Outra característica inerente ao ato administrativo é o da exigibilidade. Este atributo permite ao Poder Público compelir o administrado à obediência através de meios indiretos, cujo exemplo típico são as multas. Nem sempre a exigibilidade é exercida diretamente em relação ao sujeito passivo, como no caso de não se tratar de ato administrativo restritivo de liberdade, mas, ao contrário, de ato ampliador da faixa de interesses do sujeito passivo. Neste caso, quando ao administrado é oferecida determinada vantagem, que será desfrutada ou não de acordo com sua vontade, o Poder Público estará exercendo sua função impositiva sobre terceiros que, de algum modo, impeçam ou imponham dificuldades ao administrado no exercício de sua vontade em desfrutar tal vantagem.

No primeiro bloco de características que abordamos, ressaltamos aquelas que dizem respeito diretamente à proteção dos administrados, daí porque são consideradas garantias. Neste segundo foram arrolados atributos que beneficiam o ato administrativo, fornecendo, desta forma, instrumentos legítimos à Administração Pública para o desempenho pleno de suas atribuições e com o máximo de eficácia. Tais instrumentos, quais sejam, a imperatividade, a presunção de legitimidade e a exigibilidade, figuram, entre outros, como traços de distinção entre o ato administrativo e o ato de direito privado.

Resta-nos, ainda, levantar um terceiro grupo de traços típicos do ato administrativo, desta feita em contraposição a outros atos estatais: legalidade, revisibilidade, parcialidade e hierarquia.

\footnotetext{
${ }^{11}$ Em notável observação nos ensina Miguel Reale (Revogação e Anulamento do Ato Administrativo, $2^{\mathrm{a}}$ ed., Forense, Rio de Janeiro, 1980. p. 7) ao referir que "o horizonte do Estado é o da legalidade". E ressalta: "Isto não equivale, todavia, a dizer que a atividade do Estado deve se circunscrever à simples execução das leis existentes. Como pondera Otto Mayer, "é necessário viver e agir, mesmo em não havendo leis para dirigir a atividade do Estado; há, na Administração uma multidão de coisas que não podem ser previstas por regras estritas que as estrangulariam. O Estado de Direito (Rechtsstaat) deve, por conseguinte, restringir as suas exigências ao plano do possível, podendo o seu princípio ser assim formulado: a ação da Administração deve ser dirigida, na medida do possível, por regras de direito".
} 


\section{b) Ato administrativo e os outros atos estatais.}

$\mathrm{O}$ ato administrativo está subordinado ao princípio da legalidade. Porque sua função é executar a lei, só é admissível sua produção em nível sub-legal, ou seja, em subordinação à lei.

De modo inverso sucede com o ato legislativo, a lei. Este encontrase diretamente subordinado à Constituição. Assim sendo, estas duas espécies de atos ocupam posições distintas na hierarquia das normas. Enquanto a lei encontra seu fundamento de validade na Constituição, o ato administrativo obtém sua validade na lei.

$\mathrm{O}$ ato administrativo distingue-se ainda de determinados atos chamados de políticos ou de governo que são da competência do Poder Executivo, e produzidos, não em nível sub-legal, mas em nível subconstitucional.

Em relação ao ato jurisdicional, por outro lado, o ato administrativo apresenta um traço de igualdade já que um e outro são produzidos em nível sub-legal. Aparta-se daquele, todavia, no que tange à força jurídica na interpretação da lei. A verdadeira interpretação legal, a que tem força de coisa julgada, é aquela resultante dos atos jurisdicionais. Ao contrário, o ato administrativo está sempre sujeito à revisão pelo poder jurisdicional, condição esta resultante do caráter transitório de que se reveste a interpretação das leis, efetuada pela Administração Pública.

No ato administrativo o Estado figura como parte interessada no cumprimento de um interesse jurídico que the compete observar; no ato jurisdicional figura o Estado acima do conflito de interesses, ou seja, ocupa uma posição superior e estranha aos interesses; e o ato legislativo ocupa-se, pura e simplesmente da definição e demarcação dos termos indicativos dos vários interesses.

A produção do ato administrativo se dá dentro de uma hierarquia. Isto significa que um ato será sempre superior ou inferior a outro. Desta forma estará sempre sujeito aos limites impostos por outros atos administrativos que ocupam posição hierárquica superior ${ }^{12}$. Tal não acontece com os atos legislativos e jurisdicionais, posto que entre estes não há hierarquia. Uma lei não pode impor restrições a outra porque em termos de valor elas estão no mesmo plano. Do mesmo modo, um ato juridicional, mesmo que emanado de instância superior, não tem poder de impor um conteúdo decisório a outro de instância inferior. Tanto os atos legislativos como os atos jurisdicionais, portanto, encontram-se, dentro de sua esfera própria de produção, em nível de igualdade.

\footnotetext{
${ }^{12}$ Ruy Cirne Lima (Princípios de Direito Administrativo, $5^{\text {a }}$ ed., Ed. Revista dos Tribunais, São Paulo, 1982. p. 154) diz que “. . . a subordinação hierárquica, as mais das vezes, antes se estabelece entre os atos, do que entre os indivíduos: - o inferior delibera validamente; o superior, porém, poderá cassar-lhe a deliberação".
} 


\section{CONCEITO DE ATO ADMINISTRATIVO.}

Evidenciados os traços característicos dos atos praticados pelo Poder Público no exercício da função administrativa, podemos não só verificar que tais atos, pelas características que the são peculiares, são perfeitamente diferençáveis dos demais atos estatais e dos atos de direito privado, como também, pelas mesmas características, podem ser perfeitamente considerados como constitutivos de um bloco unitário. Isto permite que sejam tais atos agrupados sob uma denominação própria, comum - de atos administrativos.

Tendo em vista o fato de termos nos valido, nesta parte do estabelecimento das características diferenciais do ato administrativo, do critério apresentado pelo Professor Celso Antônio Bandeira de Mello, para finalizar este tópico e no, sentido de manter a coerência com o que até aqui ficou averbado, concluímos com o conceito do eminente mestre: "Ato Administrativo é a declaração do Estado ou de quem Ihe faça as vezes, expedida em nível inferior à lei - a título de cumprí-la - sob regime de direito público e sujeito a controle de legitimidade por órgão jurisdicional". ${ }^{13}$

${ }^{13}$ Op. ct., p. 31 . 


\section{CAPITULO III}

\section{ESTRUTURA DO ATO ADMINISTRATIVO}

\section{ANATOMIA DO ATO ADMINISTRATIVO.}

Chegamos assim ao tópico principal deste trabalho. Conforme já salientamos, um exame da doutrina nos revela grandes discordâncias conceituais, muito embora nos permita observar, por outro lado, um ponto de convergência entre as conceitos e que é justamente a utilização da expressão ato administrativo para se referir a atos típicos do Poder Executivo.

Dissemos ser necessária a exata noção de ato administrativo para se poder distinguí-lo dos demais atos do poder estatal. Esta distinção, contudo, se nos afígura relevante tão somente no plano teórico. Ao adentrarmos no plano prático, na realidade prática da Administração Pública, na atuação dinâmica e viva de seus órgãos, surge outro ponto de maior relevância: a validade do ato administrativo. Para julgar esta validade, a nosso juízo, não são suficientes apenas as características do ato.

Tomando de empréstimo expressões das ciências biológicas podemos dizer que se faz necessário, para responder a indagação de se é válido o ato, o conhecimento da gênese e da anatomia do ato administrativo. Conhecidas estas, ao exame ter-se-á condições de se constatar a presença de manifestações patológicas ${ }^{14}$ ou concluir-se pela sua higidez. Tal constatação é de suma importância já que permitirá prescrutar o surgimento de inúmeras e distintas conseqüências, sobretudo e principalmente aquelas ligadas aos vícios do ato administrativo. Importante também por permitirem a determinação e identificação de um defeito capaz e por si só suficiente para provocar a invalidade do ato.

Esta não é uma questão pacífica, contudo. Os administrativistas, na sua grande maioria, propõem uma decomposição do ato administra-

\footnotetext{
${ }^{14}$ Alguns administrativistas, citando Umberto Fragola, fazem referência à "patologia" do ato usando, ao nosso ver, incorretamente o termo pois quando falam de "patologia" querem referir-se aos vícios que o ato pode eventualmente apresentar. Patologia é a parte da medicina que se ocupa das doenças, suas origens, sintomas e natureza. A terminologia correta, já que se quer lançar mão de termos de outras ciências, seria estados patológicos, ou manifestações patológicas. Ou, de outro modo, como o faz André Gonçalves Pereira (Erro e Ilegalidade no Acto Administrativo, ed. Âtica, p. 106) que registra com absoluto acerto: "Aliás, o escopo prático do estudo dos elementos do ato administrativo é o de permitir a descrição dos vícios do ato, isto é, a "anatomia" é um ponto de passagem indispensável para a "patologia. do ato". Dá o au tor o sentido correto ao vocábulo, quando refere a patologia como descrição dos vícios do ato.
} 
tivo, elaborando amplo trabalho em torno do tema no intuito de destacar do ato os seus elementos constitutivos.

Deparamos com opiniões bastante divergentes não só quanto à quantidade e identidade de elementos considerados necessários à constituição do ato administrativo, como também quanto à terminologia adotada para qualificá-los. Quer nos parecer, porém, que as divergências são puramente terminológicas e que todos os autores seguem linha igual. Uns consideram cinco os elementos, outros quatro, três, etc. Alguns estabelecem distinção entre pressupostos e elementos essenciais; alguns se referem a cláusulas essenciais e cláusulas acidentais; outros, ainda, fazem referência a elementos ou requisitos, ao contrário de uns que distinguem elementos dos requisitos. Mas se constata que os desencontros são puramente verbais, apenas de rotulagem distinta para elementos que se identificam em suas significações essenciais. $^{15}$

Essa diversidade classificatória e terminológica não nos impede de agrupar em cinco os elementos que aparecem mais constantemente nas formulações propostas pelos autores, como seja: sujeito, objeto, forma, motivo e finalidade.

\section{A) ELEMENTOS DO ATO ADMINISTRATIVO.}

a) Sujeito: é a pessoa física que, fazendo as vezes do Estado, pratica $\mathrm{O}$ ato administrativo. É quem produz o ato, portanto. Adotam esta denominação, entre outros, Carlos Garcia Oviedo ${ }^{16}$, Guido Zanobini ${ }^{17}$ e, entre nós, Celso Antônio Bandeira de Mello ${ }^{18}$ que coloca o sujeito como um pressuposto do ato, por considerar que quem produz algo não pode ser parte integrante daquilo que produz.

Hely Lopes Meirelles ${ }^{19}$ enumera, ao invés de sujeito, a competência definindo-a como o atributo decorrente e delimitado pela lei e que determina quem pode realizar o ato e quanto pode realizar.

Oswaldo Aranha Bandeira de Mello ${ }^{20}$ adota a noção de causa e assevera que "a causa agente ou eficiente principal é a pessoa que manifesta a vontade" e esta, como elemento do ato administrativo, é o

${ }^{15}$ Como bem observa Cassagne (Op. cit., p. 182), a falta de uma regulação normativa e o caráter de "jus in fieri" que tem o Direito Administrativo são os fatores determinantes das discrepâncias semânticas reveladas por aqueles que procuram maior originalidade. Ainda é o mestre argentino quem assevera que uma vez sejam os desacordos despidos de suas roupagens terminológicas desaparecerão as discrepâncias, posto que só o são aparentemente, uma vez que um mesmo elemento compõe a estrutura do ato com diferente denominação.

${ }^{16}$ OVIEDO, Carlos Garcia. (Derecho Administrativo; 8ª . ed., Ed. E.I.S.A. Madrid, 1962. p. 287.

${ }^{17}$ ŻANOBINI, Guido. Corso di Diritto Amnistrativo, v. 1, 6 ${ }^{\text {a }}$ ed., Dott. A. Giuffrè-Ed., Milano, 1950. p. 198.

${ }_{18}$ Op. cit., p. 56.

19 "Nenhum ato", afirma o respeitável mestre, "- discricionário ou vinculado - pode ser realizado validamente, sem que o agente disponha de poder legal para praticá-lo. Entende-se por competência administrativa a quantidade de poder legal para praticá-lo". (Op. cit., p. 156).

${ }^{20}$ Op. cit., p. 492. 
Estado, ou as pessoas que lhe façam as vezes. "Em princípio, pessoa jurídica e, excepcionalmente, pessoa natural". Ao considerar a causa como elemento do ato administrativo o autor explica que esta pressupõe a capacidade das pessoas que agem em nome do Estado para formação e expressão da vontade, ou seja, há necessidade de que se trate de atribuições a elas conferidas pela Constituição ou por lei. Além disso, o titular das atribuições de uma pessoa jurídica necessita de um atributo a mais que é a competência para o desempenho de suas atribuições, entendida esta como a quantidade de poder que the é outorgada, constitucional ou legalmente.

Cassagne $^{21}$ dá preferência ao uso da expressão subjetivo em lugar de sujeito por considerar que aquele termo guarda mais conformidade com a idéia que preside a configuração deste elemento. Para ele não é o sujeito o elemento do ato administrativo, entendendo por elemento subjetivo o conjunto de regras que dispõem sobre a atuação e faculdades das partes intervenientes e, especialmente no Direito Administrativo, a correspondente aos órgãos que integram a pessoa jurídica Estado ou entidades estatais descentralizadas.

b) Objeto. Por objeto entendem os autores, de modo geral, ser aquilo que é estabelecido pelo ato. É o que o ato dispõe juridicamente.

Objeto, na lição de Hely Lopes Meirelles, consiste na "criação, modificação ou comprovação de situações jurídicas concernentes a pessoas, coisas ou atividades sujeitas a atuação do Poder Público". ${ }^{22}$ Assevera, então, que assim entendido, o objeto identifica-se com o conteúdo do ato.

Aliás, esta identificação entre objeto e conteúdo adotada por muitos autores é motivo de crítica por parte de outros. Assim se posiciona Celso Antônio Bandeira de Mello ${ }^{23}$ ao adotar a noção de conteúdo seguindo a lição de Zanobini que estabelece distinção entre conteúdo e objeto ao afirmar que aquele é a disposição jurídica expressada no ato; o conteúdo dispõe sobre algo, sobre alguma coisa e esta é o objeto do ato.

Não nos parece que esta distinção tenha valor consistente, muito embora, por uma pura questão de simpatia pelo vocábulo demos preferência ao uso do termo conteúdo. Se atentarmos para os significados dos vocábulos temos que conteúdo é aquilo que se contém nalguma coisa e, objeto, em uma de suas várias significações, é matéria ou assunto. Assim, entendemos que não se erra ao se estabelecer sinonímia entre ambas as expressões.

A nosso juízo, tanto objeto como conteúdo referem-se a uma só realidade e que corresponde à essência do ato, escolhendo, assim, entre outras, a lição de Cassagne ${ }^{24}$ segundo quem o objeto ou conteúdo do

\footnotetext{
${ }^{21}$ Op. cit., pp. $187 / 188$.

22 Op. cit., p. 159.

23 Op. cit., p. 40.

${ }^{24}$ Op. cit., p. 201.
} 
ato administrativo consiste naquilo que o ato decide, certifica ou opina. Registre-se que o mestre argentino nesta questão partilha das idéias de muitos outros igualmente notáveis tratadistas, como, só para exemplificar, Agustin Gordillo e Manuel María Diez. Complementa, ainda, ao referir-se ao objeto ou conteúdo, que se o ato versar sobre matéria regulamentada, seu objeto estará já determinado pela norma. Se no entanto for o ato conseqüência do poder discriminatório não haverá, evidentemente, aquela predeterminação o que não exclui, todavia, a imperiosa adequação do objeto ao marco normativo geral e ao princípio da juridicidade, asseverando que o fator fundamental para que seja válido o ato é a sua conformidade com o direito positivo. Daí porque o objeto deve conter os seguintes requisitos: deve ser lícito, certo, determinado, deve ser possível física e juridicamente, ser razoável e moral.

c) Forma. $\mathrm{O}$ ato administrativo é, em princípio, essencialmente formal. A forma é a maneira pela qual o ato se exterioriza. $\mathrm{O}$ ato deve ter uma feição material que the é determinada pela forma de que se reveste no momento de exteriorizar-se e esta é imprescind ivel para que tenha como jurídica sua existência, tanto que inexistente a forma, inexiste também o ato.

Consideram a forma como elemento essencial, Hely Lopes Meirel$\operatorname{les}^{25}$, Celso Antônio Bandeira de Mello ${ }^{26}$ e Cassagne ${ }^{27}$ para quem a forma, além de ser a declaração de vontade uma vez formulada, é também o procedimento de formação da vontade administrativa e integra também os requisitos necessários de publicidade para a vigência do ato.

Não divergem os autores quanto à regra de ser escrita a forma do ato administrativo, admitindo, contudo, excepcionalmente, em casos em que a urgência ou a conveniência requeiram, outras formas distintas de expressão, como verbal, mímica ou através de sinais.

d) Motivo. Entende-se que motivo consiste na razão ou conjunto de razões que justificam a emissão do ato. Alguns administrativistas utilizam o termo causa como sinônimo de motivo, como Carlos Garcia Oviedo $^{28}$ que considera ser a causa um elemento essencial e a define como a razão determinante do ato. Hely Lopes Meirelles ${ }^{29}$ dá preferência ao uso do termo motivo e não causa para não confundir com a causa dos atos de direito privado, que tem sentido distinto do que recebe no âmbito do direito público.

Celso Antônio ${ }^{30}$ classifica o motivo como pressuposto objetivo do

\footnotetext{
${ }^{25}$ Op. cit., p. 158.

${ }^{26}$ Com absoluta razão observa Celso Antônio que pode ocorrer a ausência de prescrição legal quanto uma forma específica para um determinado ato mas não pode, porém, existir ato sem forma já que ao Direito não interessam intenção, sentimentos ou pensamentos enquanto não manifestados, isto é, exteriorizados. Sendo a forma o meio de exteriorização do ato, não se pode pensar em ato sem forma (Op., cit. p. 42).

27 Op. cit., pp. 203/204.

${ }^{28}$ Op. cit., p. 288.

${ }^{29}$ Op. cit., p. 159.

${ }^{30}$ Op. cit., p. 72 .
} 
ato porque o antecede, é externo a ele, e por isso não pode ser considerado como seu elemento. Cassagne ${ }^{31}$ também não inclui o motivo entre os elementos essenciais para que seja válido o ato (conforme enumera: subjetivo, causa, objeto, forma e finalidade), referindo-se, isto sim, ao requisito da motivação. Diz ele que a motivação é a exposição das razões que levaram o órgão a emitir o ato e a expressão dos antecedentes de fato e de direito que precedem e justificam o ditado do ato.

e) Finalidade. A finalidade corresponde aos fins que se busca atingir com a emissão do ato. Buscando os ensinamentos de Hely Lopes Meirelles $^{32}$, nos diz o ilustre mestre que a finalidade é um elemento vinculado ao ato administrativo e corresponde ao objetivo da própria Administração Pública - a realização do interesse público - de tal sorte que, desviado de tal objetivo, o ato será nulo, posto que só se concebe a atuação da Administração Pública direcionada ao interesse coletivo.

Parece ser possível afirmar, contudo, que além dessa finalidade genérica todo ato persegue uma finalidade específica, própria, que deve estar, evidentemente, adequada àquela (satisfação do interesse público). ${ }^{33}$

Celso Antônio ${ }^{34}$, referindo-se à finalidade como um pressuposto teleológico afirma que há uma correspondência desta (como o resultado visado) com a tipologia do ato administrativo. Ou seja: cada ato só pode perseguir uma finalidade específica, que lhe é própria, por ser inerente à sua categoria, segundo a disposição legal.

\section{CONCLUSĀO.}

Já dissemos, e de certo modo já demonstramos, que a doutrina não é pacífica na determinação dos elementos constitutivos do ato administrativo $€$ isto quase que exclusivamente no tocante à terminologia, que é bastante diversificada. Uma revisão bibliográfica, ainda que superficial, nos permite observar que os administrativistas, de modo geral, afinam-se pelo mesmo diapasão. Tal observação nos autoriza a concluir, repetindo afirmação de André Gonçalves Pereira ${ }^{35}$, que nesta questão dos elementos do ato administrativo "o assentimento geral é maior do que se poderia à primeira vista pensar".

A grande maioria dos tratadistas, na abordagem da teoria dos atos administrativos dedica estudos exaustivos sobre os elementos do ato, através de sua decomposição. Foi o método que seguimos, ao destacarmos, de passagem e numa palavra, os elementos que mais constantemente são indicados na doutrina. Nossa tendência, no entanto, é a de

\footnotetext{
${ }^{31}$ Op. cit., p. 212.

32 Op. cit., p. 157 .

${ }^{33}$ MEIRA, Reilda. Conceito e elementos do ato administrativo, RDP n ${ }^{\circ}$. 30, jul/ago 1974 p. 49.

${ }^{34}$ Op. cit., p. 78.

${ }^{35}$ Op. cit., p. 97.
} 
recusar a dissecção do ato administrativo preferindo adotar distinta forma de análise ${ }^{36}$. Identificamos, nesta abordagem, três fases distintas. A primeira fase antecede 0 ato e corresponde à exigência de certos requisitos, circunstâncias, condições, que são externas ao ato, não podendo, por isso, ser nominados de elementos do ato administrativo. São condições que se impõem à Administração Pública para que esta possa exercer suas funções e no exercício destas funções, a Administração manifesta sua vontade, através de procedimentos próprios, identificados como atos administrativos. Essas condições, portanto, inerentes à Administração Pública, são, em essência, uma e a mesma coisa. Neste sentido julgamos incontestável a lição do mestre portugues Afonso Rodrigues Queiró ${ }^{37}$, que se manifesta com absoluta exatidão: "O agir da Administração está sempre ligado à verificação de determinados fatos ou situações a que a norma administrativa alude. E já vimos que estes fatos, a competência e os fins ou atribuições da administração são essencialmente uma e a mesma coisa. São formas ou modos de ser duma mesma realidade, ou dum mesmo conceito jurídico que se costuma dividir e subdividir, quase diríamos para obscurecer obstinadamente os problemas do direito administrativo. $E$ diga-se entre parênteses que é por isso que se pode constatar hoje que toda a clássica teoria da estrutura do ato administrativo, que distingue nestas fases ou momentos diversos, tal como foi elaborada pela doutrina sobretudo francesa em face da jurisprudência do Conselho de Estado, está em crise".

Damos preferência à expressão requisito ${ }^{38}$ entendida como toda a condição necessária à obtenção de certo objetivo ou destinada ao preenchimento de certo desiderato. Rejeitamos a expressão elemento, por referir-se a tudo que entra na composição de alguma coisa, como parte pois de um todo. Para nós, há uma série de requisitos necessários que se impõem à formulação do ato, mais propriamente, que se impõem à Administração Pública na elaboração do ato, mas que são exteriores a ele, não constituindo partes integrantes do todo, vale dizer, o ato não é continente de tais requisitos.

Em uma segunda fase podemos observar o ato propriamente dito, que se manifesta através de um conteúdo. Aqui, sim, concordamos em aceitar a expressão elemento, que é único, porque representa o próprio ato. Neste sentido, acolhemos a opinião daqueles que afirmam

\footnotetext{
${ }^{36} \mathrm{Um}$ dos significados do termo ato é "aquilo que se fez; feito". O que está feito evidentemente requereu algumas condições, formalidades, fatores, etc. Mas uma vez feito, torna-se uma unidade e tudo o que concorreu para sua formação torna-se dela indissociável, compondo um todo.

${ }^{37}$ QUEIRO, Afonso Rodrigues. A teoria do "desvio do poder" em Direito Administrativo. RDA, vol. VI, outubro. p. 46.

${ }^{38} \mathrm{Não}$ se quer, com isto, buscar sistematização inédita, original, do tema que ora enfrenta. mos. Não fosse isto já difícil pelo tão diversificado e exaustivo trabalho desempenhado pelos mais proeminentes administrativistas patrios e estrangeiros, é para nós impossível pela pouca vivência que temos com o Dìreito Administrativo. Mas a pesquisa realizada nos conduziu a algumas convicções e conclusões que nos encorajam, mesmo prematuramente, a fazer tal proposição. Aliás, o próprio tipo de trabalho exige, como objetivo a atingir, que assim se faça.
} 
que o ato administrativo se resume em um único elemento - o conteúdo. Tudo o mais, sujeito, competência, vontade, forma, causa, finalidade, colocados na primeira fase, são antecedentes ao ato e integram uma única constelação de requisitos exteriores a ele. 'Tais aspectos vão permitir que a Administração Pública consubstancie sua declaração de vontade com conteúdo próprio. Esses aspectos, portanto, convergem a uma única manifestação que, constituindo uma unidade, um bloco indivisível, tornam-se indissociáveis do todo.

E em última e terceira fase é que serão analisados os efeitos do ato, sua perfeição, validade e eficácia. ${ }^{39}$ Examinar-sé-á, no agir da Administração, em obediência ao comando legal, se ocorreram e foram respeitadas todas as condições para que se possa determinar a validade do ato ou, ao contrário, a ocorrência de vícios.

\section{A) REQUISITOS DO ATO ADMINISTRATIVO.}

a) Sujeito. $O$ exercício da função administrativa compete a alguém que possa representar a vontade do Estado. A ação da pessoa física, portanto, produz efeitos para a pessoa estatal, dando-Ihe existência efetiva, na medida em que representa vontade e ação do Estado. Destaca-se, neste pońto, o sujeito entre os requisitos que se impõem à atuação da função administrativa. $\mathrm{O}$ sujeito antecede ao ato e, como já se afirmou, não o integra.

Com efeito, a sociedade política, através da instituição governamental, para praticar o ato administrativo, deve, antes de tudo, estar investida das necessárias atribuições, e o agente público que o pratica deve estar munido da competência específica para essa prática. Neste sentido, o conceito de sujeito abrange também o de competência. $\mathrm{O}$ sujeito, o que pela ação cria materialmente o ato administrativo, está vinculado à Administração, como órgão desta. Tal vinculação Ihe confere capacidade para a prática de atos administrativos, mas somente os atos por ele praticados dentro do âmbito das competências que the forem atribuídas no exercício de uma função pública, é que terão caráter de atos administrativos. Fica evidente o aspecto da especificidade da competência, isto é, o agente público, por ser titular de uma função pública, de um ofício, é competente para ditar atos administrativos, mas não qualquer tipo de ato e sim somente aqueles atribuídos a cada órgão conforme a especialização funcional que norteia a estrutura da administração.

Além das atribuições, capacidade e competência, que na verdade constituem a competência propriamente dita ${ }^{40}$, como medida ou quan-

${ }^{39}$ Sobre tais qualidades, Celso Antônio exara os seguintes conceitos: perfeição é a qualidade do ato que cumpriu e concluiu todas as fases de seu processo de elaboração. Validade é a conformidade do ato às exigências da norma. Eficácia é a qualidade do ato de disponibilidade para produção de seus típicos efeitos. (Op. cit., p. 39).

${ }^{40}$ Cassagne dá o seguinte conceito de competência: "é o conjunto de faculdades e atribuições que correspondem aos órgãos e aos sujeitos estatais.” (Op. cit., p. 188) 
tidade de poder, é exigida a inexistência de impedimentos por parte do agente que $o$ impossibilitem de praticar o ato. ${ }^{41}$

0 mestre Oswaldo Aranha Bandeira de Mello, ${ }^{42}$ ao comentar a causa agente ou eficiente principal do ato administrativo, destaca os fatores: capacidade do Estado ou de quem Ihe faça as vezes, atribuições do órgão, competência do órgão e do agente e ausência de óbices pessoais.

Grande número de administrativistas classifica a competência em razão do lugar, da matéria, do grau e em razão do tempo.

A competência em razão do lugar - territorial - limita a atuação do sujeito em circunscrições que correspondem ao campo de validade espacial.

Quanto à competência material - em razão da matéria - ficam os órgãos e sujeitos estatais adstritos a uma série de funções e atribuições para realizar tudo aquilo que esteja vinculado à realização dos objetivos de sua criação.

A competência em razão do grau, também chamada de competência vertical, diz respeito à hierarquia. A organização administrativa adota, via de regra, uma estrutura piramidal que se constitui por uma série de graus hierárquicos. 0 grau de competência decorre da posição que o órgão ocupa na pirâmide administrativa.

Pode acontecer também, que a competência esteja vinculada a um tempo de duração. Esta é denominada competência em razão do tempo, ou temporal, que delimita a atuação do sujeito a um determinado período de validade.

b) Forma. Ao analisarmos a forma dissemos que, sendo esta o modo pelo qual se exterioriza o ato, é imprescindível para que seja jurídica sua existência, tanto que, inexistente a forma inexiste também o ato. Mas a forma não diz respeito à substância do ato. Por esta razão é que não a consideramos elemento integrante do ato. Consideramos, isto sim, que o sujeito que pratica o ato obedece a determinadas formalidades para externá-lo, que Ihe darão esta ou aquela forma. Note-se que as formalidades antecedem à criação do ato, que uma vez criado possui e é um conteúdo - seu único elemento. Seguimos, neste ponto, as lições de Guido Zanobini ${ }^{43}$, considerando a forma um requisito externo ao ato.

c) Motivo. Entendido o motivo como as razões que induziram o órgão da Administração à prática do ato, forçoso é admitir ser esta uma condição antecedente e externa ao mesmo. Doutrinariamente é reconhecida esta exigência de motivar o ato, mas o fato de poder ser o motivo previsto ou não em lei, leva à indagação quanto à sua obrigatoriedade.

De modo geral nega-se a existência de obrigação genérica de motivar indistintamente todo e qualquer ato. Nesta questão, debatem-se

\footnotetext{
41,42 Op. cit., p. 493 e seguintes.

${ }^{43}$ Op. cit., pp. $203 / 204$.
} 
ainda os autores. Parece-nos bastante lúcida e convincente a lição de Celso Antônio ${ }^{44}$ quando diz que "o que torna exigente a motivação "quando não imposta explicitamente pela lei" é a necessidade de sua existência como "meio" para aferir-se a consonância do ato com as condições e finalidades normativamente previstas para ele". 0 que se exige, portanto, é que tenham estado presentes os motivos que serviram de suporte para a existência do ato" e não que se haja dado notícia deles".

Conclui-se - embora nem sempre seja obrigatória a enunciação do motivo - ser obrigatória sua existência ao tempo de produção do ato.

d) Finalidade. Quanto à finalidade não julgamos necessário acrescentar nada além do que já ficou dito anteriormente. Só nos resta anotar que sendo a finalidade algo que se busca atingir com a emissão do ato ela não é sua parte porque está fora dele. Ainda vale repetir que a finalidade do ato administrativo é, em última análise, a finalidade e razão de ser da Administração Pública.

\section{B) O PAPEL DA VONTADE NO ATO ADMINISTRATIVO.}

Expostos os requisitos do ato administraitvo, podemos falar do conteúdo, já que consideramos este o único elemento no qual se resume 0 ato.

Antes, entretanto, faremos algumas considerações sobre o papel da vontade na formação do ato administrativo. Julgamos este o momento oportuno para tal análise já que sendo o conteúdo a essência do ato ele é o próprio ato e portanto uma declaração de vontade.

Talvez, entre todas as discordâncias anotadas na abordagem do ato administrativo, seja a pertinente ao papel da vontade a mais nebulosa, e, sem exagero, a mais gigantesca. Uns consideram a vontade um elemento do ato, outros, um pressuposto. Autores entendem ser este um elemento vital, enquanto outros negam tal importância.

Definida como "a faculdade de perseguir o bem, conhecido pela razão' ${ }^{\prime 45}$, temos que a vontade é princípio de atividade inteligente, de atividade livre e de atividade ordenada para o bem. Ora, sendo a vontade uma faculdade de representar mentalmente um ato, que pode ou não ser praticado em obediência ou a um impulso ou a motivos ordenados pela razão, ela só pode ser concebida como um fenômeno psicológico exclusivo dos seres racionais.. Convencionou-se, contudo, a metáfora "vontade estatal" porque o Estado, como pessoa jurídica que é, detém uma vontade e a faz manifesta por seus órgãos compostos por homens, pessoas físicas que atuam, que operam. Revestidos os agentes públicos desta qualidade de atuantes, de manifestantes da vontade estatal, suas

\footnotetext{
${ }^{44}$ Op. cit., p. 76.

45 JOLIVET, Régis. Curso de Filosofia, traduzido por Eduardo Prado de Mendonça, $9^{\mathrm{a}}$. ed. Livraria Agir Ed., Rio de Janeiro, 1968. p. 206.
} 
vontades se imputam ao ente jurídico Estado. E para que haja tal imputação o ideal é que haja coincidência da vontade psicológica do agente com a vontade técnica ou normativa. $O$ ideal é que o agente assuma, de forma absoluta e fiel, este seu papel social de dar vida ao ente inerte Estado.

A vontade normativa está sempre e necessariamente presente no ato administrativo, mas não é um elemento do ato. $\mathrm{Na}$ expressão de Cassagne $^{46}$ a vontade é condicionada pelos demais elementos (subjetivo, causa, objeto, forma, finalidade) na medida em que estes são seus condicionantes e componentes de sua estrutura. ${ }^{47}$

Consideramos bastante elucidativa a análise efetuada pelo mestre português André Gonçalves Pereira ${ }^{48}$, razão pela qual, e porque concordamos com seu posicionamento, anotamos resumidamente suas conclusões pertinentes à vontade.

- Para analisar o papel da vontade no ato administrativo, interessa, antes de tudo, estabelecer a distinção entre atividade vinculada e atividade discricionária.

- Há sempre vontade normativa no ato vinculado.

- Nem sempre há vontade psicológica no ato vinculado.

- Para que ocorra a vontade normativa na atividade discricionária é indispensável a produção da vontade psicológica.

Conclui-se que na atividade absolutamente vinculada não tem qualquer relevância a vontade psicológica do agente. E aqui vale lembrar o exemplo por todos os autores mencionado, exposto por Forsthoff, para demonstrar essa irrelevância, afirmando que seria válido o ato obrigatório e totalmente vinculado praticado por um louco. Já não teria validade, ao contrário, um ato discricionário praticado por um louco porque exigiria o pronunciamento de uma vontade psicológica. 0 que sucede, neste tipo de ato, é que a norma legal faz coincidir as duas vontades. Vale dizer, dentro da margem de liberdade que o agente público tem para atuar discricionariamente é ele dirigido pela sua vontade psicológica que deverá coincidir com os termos da lei; ela deve ser a expressão da vontade da Administração Pública, pois só desta forma é que estarão resguardadas as finalidades do ato e a própria finalidade da Administração de satisfazer o interesse público. ${ }^{49}$

\footnotetext{
${ }^{46}$ Op. cit., p. 185.

47 (Op. cit., p. 105). No mesmo sentido André Gonçalves Pereira afirma não ser a vontade um elemento (e porisso integrante do ato) mas sim uma consequiência legal da união de todos os seus elementos, isto é, a "vontade é uma conseqüência imputada pela lei".

48 Op. cit., p. 103.

${ }^{49}$ Neste sentido, lembra Bielsa que a correlação necessária entre a vontade real e a vontade declarada, mesmo que na formação do ato participem vários órgãos ou agentes, se justifica pela própria natureza da atividade administrativa (Derecho Administrativo, $5^{\mathrm{a}}$. ed., v. II, Roque Depalma ed., Buenos Aires, 1955. p. 18)
} 


\section{C) ELEMENTO DO ATO ADMINISTRATIVO}

Conteúdo. Em face de ponderações já anteriormente exaradas, destacamos o conteúdo como o único elemento do ato administrativo já que ele é o próprio ato.

$\mathrm{O}$ ato administrativo tem um conteúdo essencial que é o que o tipifica, distingue e individualiza.

Pode ter, além deste, um conteúdo acidental que se consubstancia através de disposições eventuais, quais sejam: termo, condições e encargo. Tais cláusulas, que podem ampliar ou restringir o conteúdo essencial do ato, pelo seu caráter de conteúdo acidental, não decorrem de lei e sim de decisões do agente público no exercício do poder discricionário. Convém ressaltar que no direito público estas cláusulas são excepcionais.

Pela cláusula da condição, que pode ser suspensiva ou resolutiva, o nascimento e a extinção dos efeitos do ato ficam vinculados a um evento futuro e incerto.

Já o termo, ou prazo, se refere a evento futuro, e certo ao qual ficam condicionados o início e o fim do tempo em que o ato produz efeitos jurídicos.

Encargo, ou modo, é uma obrigação imposta ao particular, a fim de que, na qualidade de beneficiário do ato, possa desfrutar de seus efeitos.

Tornamos a repetir que o conteúdo do ato para ser válido deve ser lícito, certo, determinado, possível, razoável e moral, garantias que afiançam o cumprimento dos objetivos primaciais a que ele se destina.

Somente sob tais condições terá a sociedade política segurança e certeza de que estarão sendo respeitados os objetivos visados no momento de sua organização jurídica, quando se colocou em primeiro plano a utilidade pública na hierarquia dos valores da ordem social. 


\section{BIBLIOGRAFIA}

1 ALESSI, Renato. Instituciones de Drecho Administrativo, $3^{\mathrm{a}}$. ed., v. 1, Trad. de Buenaventura Pellisé Prats, Barcelona, Bosch ed., 1970.

2 ALMEIDA, Fernando Henrique Mendes de. Os atos administrativos na teoria dos atos jurídicos, São Paulo, Revista dos Tribunais ed., 1969.

3. BIELSA, Rafael. Derecho Administrativo, $5^{\text {a }}$. ed., V. II, Buenos Aires, Roque Depalma ed., Buenos Aires, 1955.

4. CASSAGNE, Juan Carlos. El Ato Administrativo, $2^{\text {a }}$. ed. Buenos Aires, Abeledo-Perrot.

5. FORTSHOFF, Ernst. Tratado de Derecho Administrativo, Instituto de Estudios Politicos, Madrid, 1958.

6. GOFFI, Ana Maria. Extinção dos atos administrativos. RDP, nº. 30, Jul/Ago, 1974 p. 35.

7. ) GORDILLO, Agustin. Princípios Gerais de Direito Público, Trad. de Marco Aurélio Greco, São Paulo, Revista dos Tribunais ed., 1977.

8. JOliVET, Régis. Curso de Filosofia, trad. de Eduardo Prado de Mendonça, 9a . ed., Rio de Janeiro, Livraria Agir ed., 1968.

9. LIMA, Ruy Cirne. Princípios de Direito Administrativo, $5^{\mathrm{a}}$. ed., São Paulo, Revista dos Tribunais ed., 1982.

10. MEIRA, Reilda. Conceito e elementos do ato administrativo, RDP, $\mathrm{n}^{0}$. 30, Jul/ Ago/1974. p. 42.

11. MEIRELlES, Hely Lopes. Direito Administrativo Brasileiro, $2^{\mathrm{a}}$. ed., São Paulo, Revista dos Tribunais ed., 1966.

12. MEllo, Celso Antônio Bandeira de Mello. Elementos de' Direitc Administrativo, $1^{\text {a }}$. ed., Revista dos Tribunais ed. São Paulo, 1983.

13. - . Ato Administrativo e Direitos dos Administrados, São Paulo, Revista dos Tribunais ed. 1981.

14. MELlo, Oswaldo Aranha Bandeira de. Princípios Gerais de Direito Administrativo, $2^{\mathrm{a}}$. ed., v. 1, Rio de Janeiro, Forense, 1979.

15. MONTEIRO, Washington de Barros. Curso de Direito Civil, $1^{\circ}$. v., $11^{\mathrm{a}}$. ed., São Paulo, Saraiva, 1972.

16. OliveIRA, Fernando Andrade de. Conceituação do Direito Administrativo, Curitiba, Anais do I Congresso Brasileiro de Direito Administrativo, 1975.

17. OVIEDO, Carlos Garcia. Derecho Administrativo, $8^{\mathrm{a}}$, ed., Madrid, E.I.S.A. ed., 1962.

18. PEREIRA, André, Gonçalves. Erro e Ilegalidade no Acto Administrativo, Edições Ātica.

19. QUEIRO, Afonso Rodrigues. A teoria do "Desvio do Poder" em Direito Administrativo, RDA, v. VI, Out/1946.

20. REALE, Miguel. Revogação e Anulamento do Ato Administrativo, $2^{\mathrm{a}}$. ed., Rio de Janeiro, Forense, 1980.

21. TIVARONI, Carlo. (Teoria Degli Atti Amministrativ, G. Giappichelli ed., Torino, 1939.

22. PROSPER, Weil. O Direito Administrativo, Trad. de Maria da Glória Ferreira Pinto, Coimbra, Livraria Almedina, 1977.

23. ZANOBINI, Guido. Corso di Diritto Amministrativo, v. 1, $6^{\mathrm{a}}$. ed., Milano, Dott. A Giuffrè ed., 1950. 